\title{
Pengaruh Partisipasi Penganggaran Dan Komitmen Organisasi Terhadap Senjangan Anggaran Dengan Ketidakpastian Lingkungan Sebagai Variabel Moderasi
}

\author{
I Made Putra Wirya Brata ${ }^{1}$ \\ Luh Gede Krisna Dewi ${ }^{2}$ \\ ${ }^{1}$ Fakultas Ekonomi dan Bisnis Universitas Udayana (Unud), Bali - Indonesia \\ email: wiryaais@gmail.com / Telp: 081339660206 \\ ${ }^{2}$ Fakultas Ekonomi dan Bisnis Universitas Udayana (Unud), Bali - Indonesia
}

\begin{abstract}
ABSTRAK
Teori keagenan menyatakan adanya praktik senjangan anggaran dipengaruhi oleh pemberian wewenang dari pemilik perusahaan (principal) kepada manajer (agent) untuk ikut serta dalam proses perumusan anggaran (partisipasi penganggaran) sringkali disalah gunakan. Tujuan dari penelitian ini adalah untuk memperoleh bukti empiris mengenai pengaruh partisipasi anggaran dan komitmen organisasi terhadap senjangan anggaran dengan ketidakpastian lingkungan sebagai variabel moderasi. Penelitian ini dilakukan pada seluruh hotel berbintang yang terdapat di kota Denpasar pada tahun 2017. Metode pengambilan sampel menggunakan purposive sampling. Jumlah sampel penelitian ini adalah sebanyak 14 hotel. Teknik analisis data yang digunakan adalah uji Moderated Regression Analysis (MRA). Berdasarkan hasil pengujian, dapat disimpulkan bahwa partisipasi penganggaran berpengaruh positif terhadap kesenjangan anggaran, komitmen organisasi berengaruh negatif terhadap kesenjangan anggaran, ketidakpastian lingkungan memperkuat hubungan partisipasi anggaran terhadap senjangan anggaran ditolak, ketidakpastian lingkungan memperlemah hubungan komitmen organisai terhadap senjangan anggaran diterima.
\end{abstract}

Kata Kunci: Senjangan anggaran, Partisipasi penganggaran, Komitmen organisasi, Ketidakpastian Lingkungan

\begin{abstract}
Agency theory suggests the existence of budget slack practices influenced by the authorization of the principal to the manager to participate in the budget formulation process (budgetary participation) is often misused. The purpose of this study is to obtain empirical evidence regarding the influence of budgetary participation and organizational commitment to budgetary slack with environmental uncertainty as a moderating variable. This research was conducted on all star hotels located in Denpasar city in 2017. The sampling method using purposive sampling. The number of samples of this study are 14 hotels. Data analysis technique used is Moderated Regression Analysis (MRA). Based on the test results, it can be concluded that budgetary participation has a positive effect on budgetary gaps, organizational commitment negatively affect the budget gap, environmental uncertainties strengthen the relationship of budget participation against budget slack is rejected, environmental uncertainty weakens organizational commitment relationship to budget slack is accepted.

Keywords: Budget slack, Budgetary participation, Organizational commitment, Environmental Uncertainty
\end{abstract}


I Made Putra Wirya Brata dan Luh Gede Krisna Dewi. Pengaruh...

\section{PENDAHULUAN}

Lingkungan usaha yang semakin kompetitif membuat persaingan bisnis semakin ketat, memaksa para pelaku bisnis agar mengelola usahanya secara lebih efektif dan efisien agar memungkinkan memenangkan pasar bisnis. Salah satu alat agar operasional perusahaan dapat berjalan efektif dan efisien adalah dengan menggunakan anggaran sebagai alat perencanaan dan pengendalian perusahaan. Menurut Suartana (2010:138), anggaran mencerminkan tujuan detail perusahaan dan perencanaan untuk mencapainya dengan sumber daya yang terbatas. Penggunaan anggaran sebagai penilaian kerja dapat menimbulkan terjadinya disfungsional behavior atau penyimpangan perilaku para bawahan. Salah satu bentuk disfungsional behavior yang terjadi yaitu senjangan anggaran (Faria, 2013).

Senjangan anggaran adalah selisih antara sumber daya yang sesungguhnya diperlukan untuk menyelesaikan pekerjaan secara efektif dengan sejumlah sumber daya yang ditambahkan untuk menyelesaikan pekerjaan tersebut (Siegel dan Marconi, 1989). Menurut Tagwireyi (2012), para manajer akan cenderung menganggarkan pendapatan lebih kecil (understate revenue) dan menganggarkan tingkat biaya lebih besar (overstate cost). Alasan dilakukannya senjangan anggaran oleh para manajer adalah untuk menyediakan margin keselamatan (margin of safety) agar dapat memenuhi tujuan yang telah dianggarkan (M. Faruq, 2013). Partisipasi dalam perumusan anggaran juga memberikan kewenangan kepada manajer pusat pertanggungjawaban untuk menetapkan isi dari anggaran yang disusunnya. Sujana (2010) Menyatakan Pemberian kewenangan ini dapat 
menimbulkan kesempatan bagi para manajer untuk menyalahgunakan kewenangan yang dimilikinya dengan memudahkan pencapaian anggaran sehingga dapat menimbulkan kerugian bagi perusahaan. Berdasarkan penelitian terdahulu yang dilakukan mengungkapkan bahwa terdapat pengaruh positif antara partisipasi angaran terhadap senjangan anggaran (Nitiari, 2014). Hal ini sejalan dengan penelitian yang dilakukan oleh Veronica dan Komang (2009), Armaeni (2012), Apriadinata dkk. (2014) dan Lestari (2015), yang berpendapat bahwa partisipasi penganggaran memiliki pengaruh positif terhadap senjangan anggaran. Hasil dari penelitian mereka membuktikan bahwa jika adanya partisipasi yang tinggi dalam proses perumusan anggaran dapat mengakibatkan senjangan anggaran yang tinggi pula.

Timbulnya senjangan anggaran tergantung pada sejauh mana individu lebih mementingkan diri sendiri atau bekerja demi kepentingan organisasi (Sujana, 2010). Dengan adanya komitmen organisasi tingkat keterikatan individu kepada organisasi dapat dilihat dengan adanya keyakinan dan ingin mempertahankan keikutsertaan dalam organisasi tersebut (Soejoso, 2004 dalam Nitiari, 2014). Beberapa penelitian sebelumnya mengungkapkan bahwa komitmen organisasi memiliki pengaruh negatif terhadap senjangan anggaran, seperti studi yang dilakukan oleh Nitiari (2014) dan Dewi (2014).

Selain partisipasi penganggaran dan komitmen organisasi terdapat faktor lain yang dapat meningkatkan dan menurunkan terjadinya senjangan/ slack yaitu ketidakpastian lingkungan. Seorang bawahan yang mempunyai partisipasi tinggi dalam penyusunan anggaran dan menghadapi ketidakpastian lingkungan yang 
I Made Putra Wirya Brata dan Luh Gede Krisna Dewi. Pengaruh...

rendah, akan mampu menciptakan senjangan dalam anggaran, karena ia mampu mengatasi ketidakpastian dan mampu memprediksi masa mendatang. Sebaliknya, dalam ketidakpastian lingkungan yang tinggi, akan semakin sulit untuk memprediksi masa depan dan semakin sulit pula menciptakan senjangan anggaran (Ikhsan dkk, 2007). Nitiari (2014) menyatakan semakin tinggi komitmen organisasi dalam ketidakpastian lingkungan yang rendah dan tinggi semakin rendah/ memperlemah terjadinya senjangan anggaran. Komitmen yang tinggi akan membuat bawahan/ individu berusaha untuk lebih mengutamakan kepentingan organisasi daripada kepentingan pribadi dalam kondisi apapun/ ketidakpastian lingkungan sehingga dapat menghindari terjadinya senjangan anggaran. Dari hasil penelitian-penelitian terdahulu, masih banyak terdapat perbedaan-perbedaan hasil seperti, partisipasi meningkatkan senjangan dan partisipasi dapat menurunkan anggaran, hal ini dikarenakan perbedaan variabel moderating yang digunakan dalam meneliti hubungan partisipasi anggaran dengan senjangan anggaran dan perbedaan obyek yang diteliti. Maka dari itu, berdasarkan hasil penelitian diatas, maka peneliti tertarik untuk menguji kembali hubungan antara variabel-variabel tersebut terhadap senjangan anggaran. Objek dari penelitian ini adalah hotel berbintang di Kota Denpasar. Lokasi penelitian ini dipilih Kota Denpasar yang terletak di tengah-tengah Pulau Bali, selain merupakan ibu kota Provinsi, Kota Denpasar juga menjadi pusat pemerintahan, pendidikan, perekonomian, pariwisata, dan pusat kegiatan lainnya. Letak yang sangat strategis baik dari segi perekonomian maupun kepariwisataan karena merupakan titik sentral berbagai kegiatan sekaligus penghubung antara kabupaten lainnya, serta memiliki akses 
yang mudah. Denpasar juga mulai melestarikan dan mengembangkan objek-objek wisata yang membuat banyaknya wisatawan yang datang semakin meningkat di Denpasar, meningkatnya wisatawan membuat tingkat pertumbuhan hotel-hotel di Denpasar semakin berkembang dari sisi fasilitas maupun kualitas. Berdasarkan latar belakang yang telah disampaikan, maka peneliti mengusulkan penelitian dengan judul, Pengaruh Partisipasi Penganggaran, dan Komitmen Organisasi Terhadap Senjangan Angggaran dengan Ketidakpastian Lingkungan sebagai Variabel Moderasi (Studi Empiris pada Hotel berbintang di Kota Denpasar) Rumusan masalah yang dapat diajukan yaitu Apakah partisipasi penganggaran berpengaruh positif terhadap senjangan anggaran di Hotel berbintang Kota Denpasar?, Apakah komitmen organisasi berpengaruh negatif terhadap senjangan anggaran di Hotel berbintang Kota Denpasar?, Apakah ketidakpastian lingkungan memoderasi pengaruh antara partisipasi penganggaran dan senjangan anggaran di Hotel berbintang Kota Denpasar?, serta Apakah ketidakpastian lingkungan memoderasi pengaruh antara komitmen organisasi dan senjangan anggaran di Hotel berbintang Kota Denpasar?.

Tujuan penelitian ini diharapkan dapat menjadi bukti empiris yang menambah wawasan ilmu kepada akademisi dibidang akuntansi keuangan, khususnya mengenai pengaruh partisipasi penganggaran dan komitmen organisasi dengan ketidakpastian lingkungan sebagai variabel moderasi.

Jensen dan Meckling (1976) mendefenisikan teori keagenan sebagai hubungan kontraktual antara dua pihak, yaitu pihak pemilik perusahaan sebagai principal dengan pengelola perusahaan atau manajemen sebagai agent. Pihak 
I Made Putra Wirya Brata dan Luh Gede Krisna Dewi. Pengaruh...

principal merupakan pihak yang memberikan wewenang dalam mengelola perusahaan kepada pihak agent. Pemisahan fungsi dalam teori agensi dilakukan agar kepemilikan dan pengelolaan perusahaan menjadi lebih professional sehingga principal mendapatkan utilitas yang lebih baik dan maksimal. Namun, pemisahan fungsi ini menimbulkan suatu permasalahan yang disebut dengan masalah keagenan (agency problem). Konflik ini terjadi karena pihak manajemen memiliki peluang untuk mencapai keinginan pribadi mereka dan mengabaikan kepentingan dan keinginan dari pihak principal selaku pemilik perusahaan.

Teori Kontigensi dikenalkan oleh Lawrence dan Lorsch (1967). Teori ini kemudian digunakan oleh Kast dan Rosenzweig (2007) yang menyatakan bahwa sebuah organisasi tidak memiliki metode terbaik dalam memperoleh keserasian antara factor lingkugan internal organisasi maupun factor lingkungan eksternalnya untuk dapat mencapai prestasi terbaik. Pendekatan kontigensi menurut Otley (1980) digunakan untuk melihat hubungan variable-variable konteksual seperti ketidakpastian lingkungan, ketidakpastian strategi, ketidakpastian tugas, struktur dan kultur organisasi, dengan system akuntansi manajemen. Pendekatan kontigensi diperlukan untuk mengevaluasi factor-faktor kondisional yang menyebabkan system akuntansi manajemen lebih efektif.

Anggaran merupakan rencana tertulis mengenai kegiatan suatu organisasi yang dinyatakan secara kuantitatif untuk jangka waktu atau periode tertentu dan umumnya dinyatakan dalam satuan uang Alfebriano (2013). Definisi partisipasi anggaran menurut Falikhatun (2007) dalam Alfebriano (2013) adalah proses yang menggambarkan individu-individu terlibat dalam penyusunan anggaran dan 
mempunyai pengaruh terhadap target anggaran dan perlunya penghargaan atas pencapaian target anggaran tersebut. Intan (2016) menyatakan bahwa Partisipasi dalam penyusunan angggaran dapat diartikan sebagai keikut sertaan manager tingkat bawah dalam memutuskan bersama dengan komite anggaran mengenai rangkaian kegiatan dimasa yang akan datang dalam mencapai sasaran anggaran. Nanda, Irfan dkk (2013) menyatakan komitmen organisasional adalah sikap karyawan untuk tetap berada dalam organisasi dan terlibat dalam upaya-upaya mencapai misi, nilai-nilai dan tujuan organisasi. Komitmen organisasional adalah sikap yang merefleksikan loyalitas karyawan pada organisasi dan proses berkelanjutan dimana anggota organisasi mengekpresikan perhatiannya terhadap organisasi dan keberhasilan serta kemajuan yang berkelanjutan (Luthans, 2012:249). Kartika (2010) berpendapat seseorang mengalami ketidakpastian karena dia merasa tidak memiliki informasi yang cukup untuk meprediksi masa depan secara akurat. Kerangka konseptual dalam penelitian ini disajikan pada gambar 1 sebagai berikut.

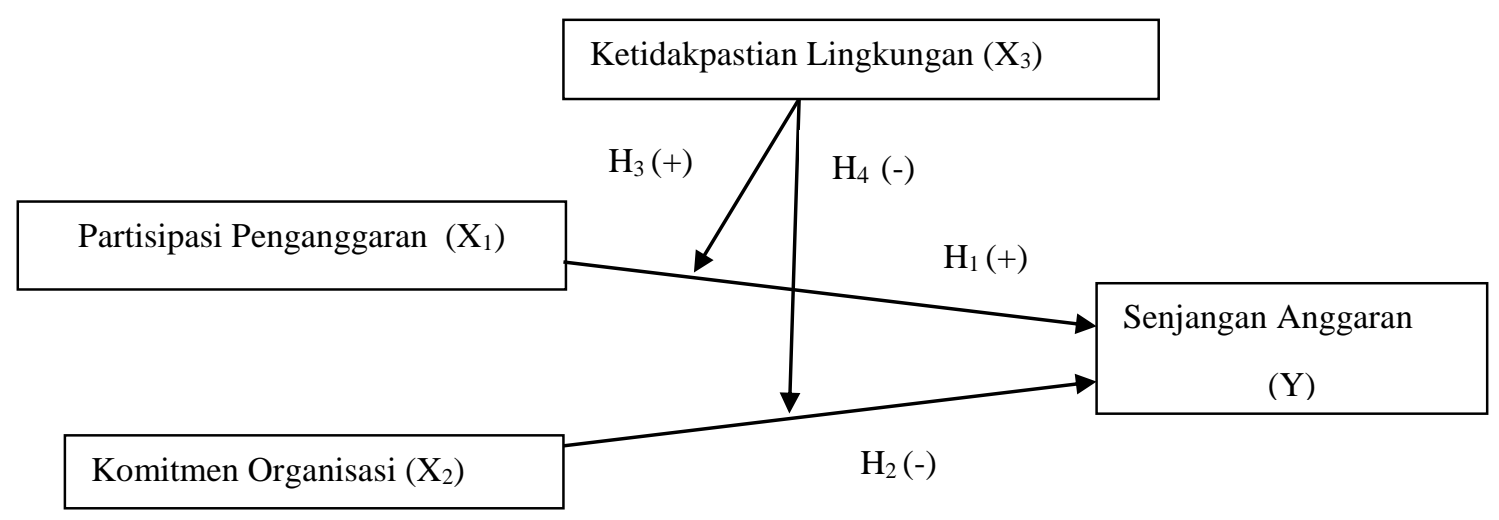

Gambar 1. Kerangka Konseptual 
I Made Putra Wirya Brata dan Luh Gede Krisna Dewi. Pengaruh...

Menurut Pratami (2016) partisipasi penganggaran memiliki pengaruh positif pada senjangan anggaran. Penelitian yang dilakukan oleh Nitiari, (2014) juga mendapatkan hasil yang sama, dimana partisipasi penganggaran berpengaruh positif pada senjangan anggaran. Apabila semakin tinggi partisipasi yang di berikan kepada manajer (agent), manajer akan cenderung melonggarkan anggaran yang disusun sehingga mudah untuk mencapainya (menciptakan kesenjangan anggaran) pada anggaran. Dari hasil penelitian sebelumnya dan studi literatur yang dilakukan peneliti, maka dirumuskna hipotesis sebagai berikut:

$\mathrm{H}_{1}$ : Partisipasi anggaran berpengaruh positif terhadap senjangan anggaran.

Menurut Dewi, (2014) terdapat pengaruh negatif antara komitmen organisasi dan senjangan anggaran. Penelitian yang dilakukan oleh Latuheru, (2005) juga mendapatkan hasil yang sama, dimana komitmen organisasi mempunyai pengaruh negatif terhadap senjangan anggaran. Darlis (2002) menunjukkan bahwa semakin besar komitmen organisasi akan menurunkan keinginan individu yang ikut berpartisipasi dalam penyusunan anggaran dalam melakukan senjangan anggaran, hal ini diperkuat dengan hasil penelitian Venusita (2006) dan Latuheru (2005) yang menyatakan bahwa komitmen organisasi mempunyai pengaruh signifikan negatif terhadap hubungan antara partisipasi dengan senjangan anggaran. Sujana (2010) menyatakan bahwa terdapat pengaruh interaksi yang negatif dan signifikan antara komitmen organisasi terhadap hubungan antara partisipasi anggaran dengan senjangan anggaran. Komitmen yang tinggi akan membuat individu berusaha lebih mengutamakan kepentingan organisasi dari pada kepentingan pribadi sehingga kesenjangan tidak akan terjadi. Sebaliknya, komitmen organisasi yang 
rendah cenderung menjadikan individu tidak bersungguh-sungguh dalam mencapai tujuan organisasi sehingga melakukan kesenjangan untuk tujuan pribadinya. Komitmen yang tinggi menjadikan individu akan peduli dengan masa depan organisasi dan senantiasa berusaha menjadikan organisasi kearah yang lebih baik. Dari hasil penelitian sebelumnya dan studi literatur yang dilakukan peneliti, maka dirumuskan hipotesis sebagai berikut:

$\mathrm{H}_{2}$ : Komitmen organisasi berpengaruh negatif terhadap senjangan anggaran Berdasarkan penelitian yang dilakukan oleh Pratami, (2016) menunjukkan bahwa ketidakpastian lingkungan memperkuat pengaruh partisipasi penganggaran pada senjangan anggaran. Menurut penelitian yang dilakukan oleh Nitiari, (2014) juga mendapatkan hasil yang sama, bahwa ketidakpastian lingkungan memperkuat pengaruh partisipasi penganggaran pada senjangan anggaran. Menurut Iksan dkk (2007), seorang bawahan yang mempunyai partisipasi tinggi dalam penyusunan anggaran dan menghadapi ketidakpastian lingkungan yang rendah, akan mampu menciptakan senjangan dalam anggaran, karena ia mampu mengatasi ketidakpastian dan mampu memprediksi masa mendatang. Dari hasil penelitian sebelumya dan studi literatur yang dilakukan oleh peneliti, maka dapat dirumuskan hipotesis sebagai berikut:

$\mathrm{H}_{3}$ : Ketidakpastian lingkungan memperkuat pengaruh partisipasi penganggaran terhadap senjangan anggaran.

Berdasarkan penelitan yang dilakukan oleh Nitiari, (2014) menyatakan bahwa ketidakpastian lingkungan memperlemah pengaruh komitmen organisasi pada senjangan anggaran. Penelitian mengenai pengaruh ketidakpastian lingkungan yang dilakukan oleh Chiristina (2009) menyatakan bahwa 
I Made Putra Wirya Brata dan Luh Gede Krisna Dewi. Pengaruh...

ketidakpastian lingkungan memperlemah pengaruh komitmen organisasi pada senjangan anggaran. Menurut Nitiari (2014) semakin tinggi komitmen organisasi dalam ketidakpastian lingkungan yang rendah dan tinggi semakin rendah/ memperlemah terjadinya senjangan anggaran. Komitmen yang tinggi akan membuat bawahan/ individu berusaha untuk lebih mengutamakan kepentingan organisasi daripada kepentingan pribadi dalam kondisi apapun/ ketidakpastian lingkungan sehingga dapat menghindari terjadinya senjangan anggaran. Dari hasil penelitian sebelumnya dan studi literatur yang dilakukan peneliti, maka dirumuskan hipotesis sebagai berikut:

$\mathrm{H}_{4}$ : Ketidakpastian lingkungan memperlemah pengaruh komitmen organisasi terhadap senjangan anggaran

\section{METODE PENELITIAN}

Penelitian yang digunakan dalam penelitian ini adalah desain asosiatif yaitu desain suatu penelitian yang meneliti pengaruh suatu variabel terhadap variabel lainnya atau untuk mengetahui hubungan antar variabel (Sugiyono, 2016:11). Penelitian ini dilakukan pada hotel-hotel berbintang yang berlokasi di Kota Denpasar. Objek pada penelitian ini adalah pengaruh partisipasi penganggaran dan komitmen organisasi, terhadap senjangan angggaran dengan ketidakpastian lingkungan sebagai variabel moderasi pada Hotel Berbintang di Denpasar.

Partisipasi anggaran merupakan proses dimana pembuat anggaran terlibat dan mempunyai pengaruh dalam penentuan besar anggaran Ardila (2013). Untuk mengukur keterlibatan dan pengaruh seorang manajer atau bawahan dalam proses penyusunan anggaran, digunakan instrumen yang dikembangkan oleh Milani 
(1975) yang digunakan oleh Ardila (2013). terdiri dari 6 item pernyataan, variabel indikator yang digunakan meliputi:

1. Keterlibatan responden dalam proses penyusunan anggaran.

2. Tingkat kelogisan alasan yang diberikan atasan dalam merevisi anggaran.

3. Intensitas atasan mengajak diskusi tentang penganggaran.

4. Besarnya pengaruh responden dalam anggaran.

5. Seberapa besar responden merasa berkontribusi pada anggaran,.

6. Frekuensi atasan meminta pendapat dalam penyusunan anggaran.

Komitmen organisasi didefinisikan sebagai dorongan dari dalam diri individu untuk berbuat sesuatu demi menunjang keberhasilan organisasi sesuai dengan tujuan dan lebih mengutamakan kepentingan organisasi diatas kepentingan pribadinya (Wiener, 1982). Untuk mengukur komitmen organisasi, digunakan instrumen pernyataan yang dikembangkan oleh (Wiguna, 2016) yang terdiri dari 8 item pernyataan, variabel indikator yang digunakan meliputi :

1. Usaha keras untuk menyukseskan organisasi.

2. Kebanggaan bekerja pada organisasi.

3. Kesediaan menerima tugas demi organisasi.

4. Kesamaan nilai individu dengan nilai organisasi.

5. Kebanggaan menjadi bagian dari organisasi.

6. Organisasi merupakan inspirasi untuk melaksanakan tugas.

7. Anggapan bahwa organisasi yang terbaik.

8. Perhatian terhadap nasib organisasi. 
I Made Putra Wirya Brata dan Luh Gede Krisna Dewi. Pengaruh...

Ketidakpastian lingkungan merupakan ketidakmampuan individu untuk menilai probabilitas seberapa besar keputusan yang telah dibuat akan gagal atau berhasil yang disebabkan karena kesulitan untuk memprediksi kemungkinan yang akan terjadi (Minanda, 2009). Untuk mengukur ketidakpastian lingkungan digunakan 12 item pernyataan yang dikembangkan oleh Duncan (1972) dalam Minanda (2009). 12 variabel indikator yang digunakan meliputi :

1. Keyakinan pada metode kerja yang digunakan.

2. Ketersediaan informasi untuk membuat keputusan.

3. Pengukuran ketepatan keputusan yang diambil.

4. Faktor-faktor yang memengaruhi pembuatan keputusan.

5. Keyakinan saat mengambil suatu tindakan.

6. Keyakinan pada tindakan penyesuaian untuk menghadapi perubahan.

7. Keyakinan pada tindakan yang tepat untuk mencapai target anggaran.

8. Mengetahui cara memeroleh informasi mengenai pekerjaan.

9. Mengetahui apa yang diharapkan oleh pihak lain untuk kemajuan instansi.

10. Kesulitan menentukan metode untuk melakukan pekerjaan.

11. Keyakinan saat melakukan pekerjaan dan.

12. Intensitas menghadapi masalah baru dalam pekerjaan

Ardila (2013) senjangan anggaran merupakan perbedaan atau selisih antara sumber daya yang sebenarnya dibutuhkan untuk melaksanakan sebuah pekerjaan dengan sumber daya yang diajukan. Pada daftar pernyataan yang dikembamgkan oleh Dunk (1993) yang digunakan oleh Ardila (2013) yang terdiri dari enam item pernyataan namun sudah di modifikasi oleh penulis menjadi 4 
item pertanyaan, karena 3 item pertanyaan dari 6 item yang digunakan oleh peneliti terdahulu memiliki arti atau pernyataan yang sama, variabel indikator yang digunakan meliputi:

1. Standar yang ditetapkann dalam anggaran mendorong produktifitas yang tinggi.

2. Kepastian mengenai terlaksananya anggaran.

3. Pengawasan pada pengeluaran yang menjadi wewenang..

4. Target anggaran yang harus dicapai.

Dalam penelitian ini yang menjadi populasi adalah seluruh hotel berbintang di Kota Denpasar Penelitian ini dilaksanakan pada Hotel berbintang di Kota Denpasar sebanyak 26 hotel. Sampel untuk penelitian ini ditentukan dengan metode purposive sampling. Pada penelitian dilakukan Uji Statistik Deskriptif, Uji Asumsi Klasik hingga Uji analisis regresi moderasi atau Moderated Regression Analysis (MRA) yang menghasilkan persamaan sebagai berikut

$\mathrm{Y}=\alpha+\beta 1 \mathrm{X} 1+\beta 2 \mathrm{X} 2+\beta 3 \mathrm{X} 3+\beta 4(\mathrm{X} 1 . \mathrm{X} 3)+\beta 5(\mathrm{X} 2 . \mathrm{X} 3)+\varepsilon$

Keterangan :

Y : Senjangan Anggaran

$\alpha \quad$ : Konstanta

$\beta 1-\beta 5$ : Koefisien Regresi

$\mathrm{X} 1 \quad$ : Partisipasi Anggaran

X2 : Komitmen Organisasi

X3 : Ketidakpastian Lingkungan

X1.X3 : Interaksi antara Partisipasi Anggaran dengan Ketidakpastian Lingkungan

X2.X3 : Interaksi antara Komitmen Organisasi dengan Ketidakpastian Lingkungan

$\varepsilon \quad$ : Error 


\section{HASIL DAN PEMBAHASAN}

Setelah dilakukan observasi penelitian, hotel yang dapat dijadikan sampel sebanyak 14 hotel dengan total 70 sampel amatan yang ditunjukan dengan distribusi sebagai berikut.

\section{Tabel 1.}

Rincian Pengiriman dan Pengembalian Kuesioner

\begin{tabular}{lc}
\hline \multicolumn{1}{c}{ Keterangan } & Jumlah \\
\hline Kuesioner yang dikirim & $\mathbf{7 0}$ \\
Kuesioner yang tidak dikembalikan & $\mathbf{7 0}$ \\
Kuesioner yang dikembalikan & - \\
Kuesioner yang gugur (tidak lengkap) & $\mathbf{7 0}$ \\
Kuesioner yang digunakan & \\
Tingkat pengembalian (response rate) & $\mathbf{1 0 0 \%}$ \\
Kuesioner yang dikembalikan x 100\% &
\end{tabular}

Kuesioner yang dikirim

Tingkat pengembalian yang digunakan (useable response rate)

Kuesioner yang diolah $\times 100 \%$

$100 \%$

Kuesioner yang dikirim

Sumber: Data primer diolah, 2018

Statistik deskriptif digunakan untuk mengetahui jumlah sampel, nilai minimum, nilai maksimum, nilai rata-rata, dan standar deviasi dari masing-masing variabel. 
Tabel 2.

Hasil Uji Statistik Deskriptif

\begin{tabular}{lccccc}
\hline & N & Minimum & Maksimum & Mean & $\begin{array}{c}\text { Std. } \\
\text { Deviation }\end{array}$ \\
& & & & & \\
\hline $\begin{array}{l}\text { Partisipasi Anggaran } \\
\text { (X1) }\end{array}$ & 70 & 7,37 & 22,64 & 16,8747 & 4,81104 \\
Komitmen Organisasi & 70 & 9,36 & 29,79 & 16,1884 & 5,94207 \\
$\begin{array}{l}\text { (X2) } \\
\text { Ketidakpastian }\end{array}$ & 70 & 12,00 & & & \\
Lingkungan (X3) & & 46,43 & 35,1111 & 9,44981 \\
Senjangan Anggaran & 70 & 4,00 & & & \\
(Y) & & & & & \\
\end{tabular}

Sumber: Data diolah, 2018

Variabel partisipasi anggaran memperoleh hasil nilai minimum 7,37 , nilai maksimum 22,64 , nilai mean 16,8747 berarti rata-rata penerapan partisipasi anggaran adalah 16,8747 dan nilai standar deviasi sebesar 4,81104 yang artinya terjadi penyimpangan nilai partispasi anggaran terhadap nilai rata-ratanya sebesar 4,81104. Untuk variabel komitmen organisasi memperoleh hasil nilai minimum 9,36, nilai maksimum 29,79 , nilai mean 16,1884 berarti rata-rata penerapan komitmen organisasi adalah 16,1884 dan nilai standar deviasi sebesar 5,94207 yang artinya terjadi penyimpangan nilai penekanan anggaran terhadap nilai rataratanya sebesar 5,94207. Variabel ketidakpastian lingkungan memperoleh hasil nilai minimum 12,00 , nilai maksimum 46,43 , nilai mean 35,1111 berarti rata-rata penerapan ketidakpastian lingkungan adalah 35,1111 dan nilai standar deviasi sebesar 9,44981 yang artinya terjadi penyimpangan nilai ketidakpastian lingkungan terhadap nilai rata-ratanya sebesar 9,44981. Sementara untuk variabel 
I Made Putra Wirya Brata dan Luh Gede Krisna Dewi. Pengaruh...

senjangan anggaran memperoleh hasil nilai minimum 4,00, nilai maksimum 15,95 , nilai mean 11,5990 berarti rata-rata penerapan senjangan anggaran adalah 11,5990 dan nilai standar deviasi sebesar 3,11991yang artinya terjadi penyimpangan nilai senjangan anggaran terhadap nilai rata-ratanya sebesar 3,11991 .

Selanjutnya dilakukan uji asumsi klasik yang meliputi uji normalitas, uji autokorelasi, uji multikolinearitas dan uji heteroskedastisitas untuk mengetahui apakah data dalam penelitian yang dilakukan telah lolos dari asumsi klasik. Berdasarkan hasil uji normalitas nilai pada koefisien Asymp. Sig (2-tailed) adalah 0,200 yang lebih besar dari 0,05 . Hal ini berarti model regresi berdistribusi normal.

Uji selanjutanya yaitu uji heteroskedastisitas dilakukan untuk mengetahui apakah dalam sebuah model regresi terjadi ketidaksamaan varians pada residual dari satu pengamatan ke pengamatan lainya. Berdasarkan hasil uji, dapat dilihat bahwa model regresi yang digunakan bebas heteroskedastisitas karena nilai sig. masing-masing variabel berada di atas 0,05 .

Uji multikolinearitas digunakan untuk menguji apakah dalam model regresi ditemukan adanya korelasi antar variabel bebas. Jika nilai toleransi lebih kecil dari 0,1 atau VIF lebih besar dari 10 maka dikatakan tidak ada multikolinearitas. Berdasarkan hasil uji multikolonieritas, keseluruhan nilai variabel yang digunakan pada penelitian ini memiliki nilai tolerance yang lebih besar dari 0,100 dan nilai VIF yang lebih rendah dari 10,00 maka dapat 
disimpulkan bahwa tidak terdapat korelasi antara variabel bebas yang digunakan pada penelitian ini.

Uji selanjutnya yaitu uji Moderated Regression Analysis. Adapun hasil dari pengujian Moderated Regression Analysis persamaan kedua pada penelitian ini disajikan pada Tabel 4. sebagai berikut

Tabel 3.

Rekapitulasi Hasil Uji Moderated Regression Analysis

\begin{tabular}{|c|c|c|c|c|c|}
\hline \multirow{2}{*}{ Variabel } & \multicolumn{2}{|c|}{$\begin{array}{c}\text { Unstandarized } \\
\text { Coefficients }\end{array}$} & \multirow{2}{*}{$\begin{array}{c}\begin{array}{c}\text { Standardized } \\
\text { Coefficients }\end{array} \\
\text { Beta }\end{array}$} & \multirow{2}{*}{$\mathrm{T}$} & \multirow{2}{*}{ Sig. } \\
\hline & B & $\begin{array}{l}\text { Std. } \\
\text { Error }\end{array}$ & & & \\
\hline (Constant) & $-3,071$ & 5,822 & & $-0,527$ & 0,600 \\
\hline $\operatorname{PAR}\left(\mathrm{X}_{1}\right)$ & 1,163 & 3,79 & 1,793 & 3,067 & 0,003 \\
\hline $\operatorname{KOG}\left(\mathrm{X}_{2}\right)$ & $-0,033$ & 0,155 & $-0,062$ & $-0,211$ & 0,033 \\
\hline $\operatorname{KLIG}\left(\mathrm{X}_{3}\right)$ & 0,374 & 0,131 & 1,132 & 2,857 & 0,006 \\
\hline $\mathrm{X}_{1} \cdot \mathrm{X}_{3}$ & $-0,012$ & 0,010 & $-0,328$ & $-1,212$ & 0,230 \\
\hline $\mathrm{X}_{2} . \mathrm{X}_{3}$ & $-0,023$ & 0,008 & $-2,028$ & $-2,981$ & 0,004 \\
\hline $\mathrm{R}$ & & & & & 0,812 \\
\hline $\mathrm{R}^{2}$ & & & & & 0,659 \\
\hline Adjusted $R^{2}$ & & & & & 0,633 \\
\hline F Hitung & & & & & 24,759 \\
\hline Sig. F & & & & & 0,000 \\
\hline
\end{tabular}

Sumber: Data diolah, 2018

Melalui pengujian Moderated Regression Analysis pada tabel 3. di atas, maka dihasilkan persamaan regresi sebagai berikut:

$Y=-3,071+1,163 X_{1}-0,033 X_{2}+0,374 X_{3}-0,012\left(X_{1} \cdot X_{3}\right)-0,023\left(X_{2} \cdot X_{3}\right)+\varepsilon$

Nilai konstanta sebesar $-3,071$. Nilai konstanta tersebut bernilai negatif memiliki arti bahwa apabila variabel partisipasi anggaran $\left(\mathrm{X}_{1}\right)$, komitmen 
I Made Putra Wirya Brata dan Luh Gede Krisna Dewi. Pengaruh...

organisasi $\left(\mathrm{X}_{2}\right)$, ketidakpastian lingkungan $\left(\mathrm{X}_{3}\right)$, interaksi antara ketidakpastian lingkungan dengan partisipasi anggaran $\left(\mathrm{X}_{1} . \mathrm{X}_{3}\right)$, dan interaksi antara ketidakpastian lingkungan dengan komitmen organisasi $\left(\mathrm{X}_{2} . \mathrm{X}_{3}\right)$ konstan atau bernilai nol, maka senjangan anggaran akan menurun sebesar -3,071.

Nilai koefisien $\beta_{1}=1,163$ menunjukan bila nilai partisipasi anggaran $\left(\mathrm{X}_{1}\right)$ meningkat sebesar 1 satuan dengan anggapan variabel lainya konstan, maka nilai dari senjangan anggaran akan mengalami peningkatan sebesar 1,163 satuan.

Nilai koefisien $\beta_{2}=-0,033$ menunjukan bila nilai komitmen organisasi $\left(\mathrm{X}_{2}\right)$ meningkat sebesar 1 satuan dengan anggapan variabel lainya konstan, maka nilai dari senjangan anggaran akan mengalami penurunan sebesar -0,033 satuan.

Nilai koefisien $\beta_{3}=0,374$ menunjukan bila nilai ketidakpastian lingkungan $\left(\mathrm{X}_{3}\right)$ meningkat sebesar 1 satuan dengan anggapan variabel lainya konstan, maka nilai dari senjangan anggaran akan mengalami peningkatan sebesar 0,374 satuan.

Nilai koefisien $\beta_{4}=-0,012$ menunjukan nilai negatif, bila nilai interaksi antara partisipasi anggaran dengan ketidakpastian lingkungan $\left(\mathrm{X}_{1} . \mathrm{X}_{3}\right)$ meningkat 1 satuan dengan anggapan variabel lainya konstan, maka nilai dari senjangan anggaran akan mengalami penurunan sebesar -0,012 satuan. Artinya semakin tinggi interaksi yang terjadi antara partisipasi anggaran dengan ketidakpastian lingkungan, maka akan menyebabkan semakin rendah senjangan anggaran yang terjadi.

Nilai koefisien $\beta_{5}=-0,023$ menunjukan nilai negatif, bila nilai interaksi antara komitmen organisasi dengan ketidakpastian lingkunga $\left(\mathrm{X}_{2} \cdot \mathrm{X}_{3}\right)$ meningkat 1 satuan dengan anggapan variabel lainya konstan, maka nilai dari senjangan 
anggaran akan mengalami penurunan sebesar -0,023 satuan. Artinya semakin tinggi interaksi yang terjadi antara komitmen organisasi dengan ketidakpastian lingkungan, maka akan menyebabkan semakin rendah senjangan anggaran yang terjadi.

Berdasarkan hasil uji kesesuaian model pada Tabel 3 di atas, diketahui nilai Sig. F sebesar 0,000 yang lebih kecil daripada 0,05 hal ini memiliki arti bahwa seluruh variabel mampu memprediksi atau menjelaskan fenomena senjangan anggaran pada hotel berbintang 5,4,dan 3 di Kota Denpasar dan model regresi yang digunakan dianggap layak uji.

Adapun nilai dari adjusted $R$ square sebesar 0,633 memiliki arti bahwa 63,3\% variasi senjangan anggaran mampu dijelaskan oleh variabel partisipasi anggaran dan komitmen organisasi serta ketidakpastian lingkungan sebagai pemoderasi. Sisanya sebesar 36,7\% dijelaskan oleh variabel lain diluar model.

Hasil analisis regresi moderasi (moderated regression analysis) dengan uji statistik tersebut menunjukkan pengaruh dari masing-masing variabel independen terhadap variabel dependen yaitu sebagai berikut.

Variabel partisipasi penganggaran $\left(\mathrm{X}_{1}\right)$ memiliki nilai t sebesar 3,067 dengan tingkat signifikansi sebesar 0,003 lebih kecil dibandingkan dengan taraf nyata $\alpha=0,05$. Hal ini menunjukkan bahwa variabel partisipasi penganggaran berpengaruh positif dan signifikan terhadap kesenjangan anggaran. Sehingga $\mathrm{H}_{1}$ yang menyatakan bahwa partisipasi penganggaran berpengaruh positif terhadap kesenjangan anggaran diterima. Hal tersebut menunjukan bahwa variabel partisipasi penganggaran berpengaruh terhadap senjangan anggaran. Hasil 
I Made Putra Wirya Brata dan Luh Gede Krisna Dewi. Pengaruh...

penelitian ini menunjukkan bahwa semakin tinggi partisipasi para manajer dalam perumusan anggaran maka senjangan anggaran akan semakin meningkat. Partisipasi yang tinggi dari para manajer menengah saat proses perumusan anggaran akan memberikan peluang yang lebih besar pada manajer menengah untuk menciptakan senjangan dan sebaliknya ketika partisipasi rendah peluang untuk melakukan senjangan anggaran menjadi terbatas sehingga akan mengecilkan peluang untuk membangun senjangan. Hasil penelitian ini konsisten dengan penelitian Desy (2016) dan Kartika (2010) dengan hasil serupa yaitu partisipasi penganggaran berpengaruh positif dan signifikan terhadap senjangan anggaran. Namun, hasil penelitian ini berbeda dengan hasil penelitian Dunk (1993), Asak (2014) dan Intan (2016) yang mengungkapkan bahwa partisipasi penganggaran yang tinggi justru berpengaruh negatif pada senjangan anggaran.

Variabel komitmen organisasi $\left(\mathrm{X}_{2}\right)$ memiliki nilai t sebesar -0,211 dengan tingkat signifikansi sebesar 0,033 lebih kecil dibandingkan dengan taraf nyata $\alpha=$ 0,05. Hal ini menunjukkan bahwa variabel komitmen organisasi berpengaruh signifikan terhadap kesenjangan anggaran. Sehingga $\mathrm{H}_{2}$ yang menyatakan bahwa komitmen organisasi berpengaruh negatif terhadap senjangan anggaran diterima. Hasil penelitian ini menunjukan dimana para manajer yang memiliki komitmen yang tinggi akan cenderung lebih mengutamakan kepentingan organisasi atau perusahaan dan memperkecil terjadinya kesenjangan anggaran. Sebaliknya jika seorang manajer memiliki komitmen organisasi yang rendah akan cenderung lebih mengutamakan kepentingan individu untuk mencapai tujuan pribadinya yang membuat terjadinya kesenjangan anggaran semakin tinggi. Hasil penelitian ini 
konsisten dengan penelitian Nitiari (2014) dan Widodo (2015) komitmen organisasional berpengaruh negatif terhadap senjangan anggaran. Semakin tinggi Komitmen Organisasional manajer terhadap perusahaan maka semakin rendah Senjangan Anggaran.

Variabel ketidakpastian lingkungan (X3) yang memoderasi pengaruh partisipasi penganggaran (X1) pada senjangan (Y) memiliki nilai t sebesar -1,212 dengan tingkat signifikansi sebesar 0,230 lebih besar dibandingkan dengan taraf nyata $\alpha=0,05$. Hal ini menunjukkan bahwa variable ketidakpastian lingkungan tidak dapat memoderasi pengaruh partisipasi penganggaran terhadap senjangan anggaran. Sehingga $\mathrm{H}_{3}$ yang menyatakan bahwa ketidakpastian lingkungan memperkuat pengaruh partisipasi penganggaran terhadap senjangan anggaran ditolak. Hal tersebut menunjukan bahwa variabel ketidakpastian lingkungan tidak mampu memoderasi secara signifikan pengaruh partisipasi penganggaran pada senjangan anggaran. Dengan demikian hipotesis ketidakpastian lingkungan sebagai variabel moderasi tidak dapat memoderasi pengaruh partisipasi penganggaran terhadap senjangan anggaran. Sehingga dapat disimpulkan bahwa kondisi ketidakpastian lingkungan tidak memperkuat atau memperlemah dalam proses partisipasi penganggaran dalam menciptakan senjangan anggaran. Dilihat dari hasil koefisien regresi mendapat hasil negatif, hal ini menunjukkan hubungan yang negatif terhadap hubungan partisipasi penganggaran dengan senjangan anggaran. Hal ini tentu bukanlah hal yang bersifat mutlak dalam mencerminkan kondisi yang sebenarnya. Peneliti mengidentifikasi hal ini terjadi karena data yang didapat tidak cukup bukti untuk menolak H0. Hal ini sesuai dengan penelitian 
I Made Putra Wirya Brata dan Luh Gede Krisna Dewi. Pengaruh...

Falikhatun (2007) dan Fatmawati (2013) yang menyatakan bahwa ketidakpastian lingkungan yang tinggi mempunyai pengaruh negatif dan tidak signifikan terhadap hubungan partisipasi penganggaran dengan budgetary slack, sehingga dapat disimpulkan bahwa ketidakpastian lingkungan bukan merupakan variabel yang memoderasi pada pengaruh partisipasi penganggaran terhadap senjangan anggaran. Tetapi tidak sejalan dengan pendapat Iksan dkk (2007), Nitiari, (2014) dan Pratami, (2016) yang menyatakan hubungan antara partisipasi dengan senjangan anggaran adalah positif dalam kondisi ketidakpastian lingkungan yang tinggi.

Variabel ketidakpastian lingkungan (X3) yang memoderasi pengaruh komitmen organisasi (X2) pada senjangan (Y) memiliki nilai t sebesar -2,981 dengan tingkat signifikansi sebesar 0,004 lebih kecil dibandingkan dengan taraf nyata $\alpha=0,05$. Hal ini menunjukkan bahwa variable ketidakpastian lingkungan mampu memoderasi pengaruh komitmen organisasi terhadap senjangan anggaran. Sehingga $\mathrm{H}_{4}$ yang menyatakan bahwa ketidakpastian lingkungan memperlemah pengaruh komitmen organisasi terhadap senjangan anggaran diterima. Hal tersebut menunjukan bahwa variabel Ketidakpastian Lingkungan mampu memoderasi secara negatif (memperlemah) pengaruh Komitemen Organisasi pada senjangan anggaran. Dengan demikian hipotesis keempat $\left(\mathrm{H}_{4}\right)$ yang menyatakan bahwa Ketidakpastian Lingkungan memperlemah hubungan Komitmen Organisasi pada senjangan angaran di hotel berbintang 5,4,dan 3 Di Kota Denpasar. Sehingga dapat disimpulkan dimana seorang manajer yang memiliki komitmen yang tinggi akan membuat manajer berusaha untuk lebih 
mengutamakan kepentingan organisasi daripada kepentingan pribadinya. Namun kondisi ketidakpastian lingkungan yang tinggi yang dihadapi para manajer hotel dalam penyusunan anggaran menjadikan tingkat komitmen organisasi para manajer menjadi rendah sehingga memungkinkan manajer untuk melonggarkan anggaran agar mudah mencapai target dan mendapatkan reward dari atasan, sehingga hal ini akan menyebabkan terjadinya senjangan anggaran. Hasil penelitian ini sejalan dengan penelitian yang dilakukan oleh Chiristina, (2009) dan Nitiari, (2014) menyatakan bahwa ketidakpastian lingkungan memperlemah pengaruh komitmen organisasi pada senjangan anggaran. Semakin tinggi ketidakpastian lingkungan membuat individu memiliki komitmen organisasi yang rendah yang cenderung mempermudah terjadinya senjangan anggaran.

Implikasi penelitian ini dibagi atas dua jenis; 1) Penelitian ini diharapkan dapat memberikan kontribusi pada studi akuntansi dan pemahaman mengenai pengaruh kinerja manajer dalam perusahaan dalam penyusunan anggaran. Hasil uji dalam penelitian ini menemukan bahwa partipasi anggaran berpengaruh positif terhadap senjangan anggaran. Hal ini sejalan dengan agency theory yang menyatakan adanya perbedaan kepentingan antara principal dan agent yang menimbulkan masalah keagenan. 2) implikasi praktis, memberikan implikasi bagi perusahaan sebagai bahan pertimbangan dalam memperbaiki dan meningkatkan pengawasan kinerja manajer dalam penyusunan anggaran pada perusahaan.

\section{SIMPULAN DAN SARAN}

Kesimpulan dari penelitian ini yaitu: 1) Hipotesis pertama $\left(\mathrm{H}_{1}\right)$ diterima dan disimpulkan bahwa partisipasi penganggaran berpengaruh positif terhadap 
I Made Putra Wirya Brata dan Luh Gede Krisna Dewi. Pengaruh...

kesenjangan anggaran; 2) Hipotesis kedua $\left(\mathrm{H}_{2}\right)$ diterima dan disimpulkan bahwa komitmen organisasi berengaruh negatif terhadap kesenjangan anggaran; 3) Hipotesis ketiga $\left(\mathrm{H}_{3}\right)$ yang menyatakan ketidakpastian lingkungan memperkuat hubungan partisipasi anggaran pada senjangan anggaran ditolak; 4) Hipotsesis keempat diterima $\left(\mathrm{H}_{4}\right)$ yang menyatakan ketidakpastian lingkungan memperlemah hubungan komitmen organisasi pada senjangan anggaran.

Adapun beberapa hal yang dapat disarankan sesuai dengan hasil pembahasan hingga kesimpulan yang disajikan pada penelitian ini meliputi: 1) Untuk peneliti selanjutnya yang tertarik untuk mengambil topik yang serupa, hendaknya dapat di sempurnakan lagi kekurangan-kekurangan dalam penelitian ini sehingga mendapatkan hasil yang lebih maksimal. Dan juga dapat menambahkan variabel independen lain yang dapat mempengaruhi terjadinya senjangan anggaran. 2) Untuk pihak Hotel / Perusahaan Lebih baik membentuk team pengawas untuk meningkatkan control pada manajer agar para manajer tidak memanfaatkan keadaan untuk mencari keuntungan tersendiri dalam pemanfaatan penyusunan anggaran dan pemilik perusahaan (principal) harus lebih memerhatikan partisipasi dari para manajer dalam perumusan anggaran dengan cara mengkaji ulang (review) rancangan anggaran yang telah dibuat oleh para manajer bawahan sebelum rancangan anggaran tersebut diberlakukan. 


\section{REFERENSI}

Ajibolade, Solabomi O., and Opeyemi Kehinde A. 2013. The Influence of Organisational Culture and Budgetary Participation on Propensity to Create Budgetary Slack in Public Sector Organisations. British Journal of Arts and Social Sciences, 13 (1), pp: 69-83.

Alfebriano. (2013). Faktor-faktor yang mempengaruhi Slack Anggaran Pada PT. BRI di Kota Jambi. E-Jurnal Binar Akuntansi. Vol. 2. No. 1.

Anthony, Robert N. dan V. Govindarajan. 2007. Management Control System, 12th Edition. New York: McGraw-Hill.

Apriadinata, Made Didik., Edy Sujana dan Made Pradana Adi Putra. 2014. Pengaruh Partisipasi Anggaran, Penekanan Anggaran, Komitmen Organisasi dan Asimetri Informasi Terhadap Slack Anggaran dengan Kompleksitas Tugas Sebagai Variabel Moderasi (Studi Kasus Pada Bank Perkreditan Rakyat di Kota Singaraja). E-Journal S1 AK Universitas Pendidikan Ganesha, 2(1) h: 65-75.

Apriantini, N.K.E, et al., 2014, Pengaruh Partisipasi Anggaran terhadap Senjangan Anggaran dengan Penekanan Anggaran dan Komitmen Organisasi Sebagai Variabel Moderating (Studi Kasus pada Dinas-dinas Pemerintah Kabupaten Buleleng), Jurnal Akuntansi, Universitas Pendidikan Ganesha. Vol. 2, No. 1.

Ardila, Lisa. 2013. Pengaruh Partisipasi Anggaran Terhadap Senjangan Anggaran Dengan Ambiguitas Peran dan Asimetri Informasi Sebagai Pemoderasi (Studi Empiris Pada Pemerintah Kota Padang). Program Studi Akuntansi Fakultas Ekonomi Universitas Negeri Padang.

Arfan Ikhsan.2008. Metode Penelitian Akuntansi Keperilakuan. Yogyakarta: Graha Ilmu.

Armaeni. 2012. Analisis Pengaruh Partisipasi Anggaran, Informasi Asimetri dan Penekanan Anggaran Terhadap Senjangan Anggaran (Budgetary Slack): Studi Pada SKPD Pemerintah Kabupaten Pinrang). Skripsi Sarjana Jurusan Akuntansi pada Fakultas ekonomi dan bisnis Universitas Hasanuddin, Makassar.

Darlis, Edfan. 2002. Analisis Pengaruh Komitmen Organisasional dan Ketidakpastian Lingkungan Terhadap Hubungan antara Partisipasi Anggaran dengan Senjangan Anggaran. JRAI 5(1): 12-21. 
Desy, Pratami. 2016. Pengaruh Partisipasi Penganggaran Terhadap Senjangan Anggaran Dengan Penekanan Anggaran Dan Ketidakpastian Lingkungan Sebagai Pemoderasi. E-Jurnal Akuntansi Universitas Udayana. Vol.15.2.

Duncan, Robert B. 1972. Characteristic of Organization Environment and Perceived Environment Uncertainty. Administration Science Quartely 17: 313-327.

Fatmawati, Ifat. 2013. Moderasi Komitmen Organisasi dan Ketidakpastian Lingkungan dalam Pengaruh Partisipasi Anggaran terhadap Senjangan Anggaran (Pada Satuan Kerja Pemerintah Daerah Kabupaten Serang). Skripsi. Universitas Pendidikan Indonesia

Faria, Juliano A., and Sonia Maria Gomes da Silva. 2013. The Effects of Information Asymmetry on Budget Slack: An Experimental Research. African Journal of Business Management, 7 (13), pp: 1086-1099.

Ghozali, Imam. 2013. Aplikasi Analisis Multivariate dengan Program SPSS Edisi 7. Semarang: Universitas Diponegoro.

Hansen, Don R. dan Maryanne M. Mowen. 2011. Akuntansi Manajerial. Buku 1 Edisi 8. Jakarta: Salemba Empat.

Ikhsan, Arfan, dan La Ane. 2007. Pengaruh Partisipasi Anggaran Terhadap Senjangan Anggaran dengan Menggunakan Lima Variabel Pemoderasi.

Simposium Nasional Akuntansi X. Unhas Makassar. 26-28 Juli 2007. ASPP-02.

Intan Priliandani Ni Made. Putra Astika Ida Bagus. 2016. Pengaruh Partisipasi Penganggaran Pada senjangan Anggaran Di Universitas Udayana Dengan Informasi Asimetri Dan Motivasi Sebagai Pemoderasi. E-Jurnal Ekonomi dan Bisnis Universitas Udayana. 5.4; 749-774).

Kartika, Andi.2010. Pengaruh Komitmen Organisasi Dan Ketidakpastian Lingkungan Dalam Hubungan Antara Partisipasi Anggaran Dengan Senjangan Anggaran.Jurnal Kajian Akuntansi, Vol. 2, No.1, Hal 39-60.

Kridawan, Aji dan Amir Mahmud. 2014. Pengaruh Kejelasan Sasaran Anggaran terhadap Senjangan Anggaran dengan Asimetri Informasi sebagai Variabel Moderasi. Accounting Analysis Journal, 3(2), pp:194-202.

Lawrence, P., and Lorsch, J., "Differentiation and Integration in Complex Organizations" Administrative Science Quarterly 12, (1967), 1-30.

Lestari, Ni Komang Tri dan IGAM Asri Dwija Putri. 2015. Pengaruh Penganggaran Partisipatif Pada Senjangan Anggaran Dimoderasi 
Ketidakpastian Lingkungan dan Komitmen Organisasi. E-Jurnal Akuntansi Universitas Udayana, 10(2) h: 474-488.

M. Faruq, Dwi Jaya. 2013. The Effects of Budget Participation, Asymmetric Information, Budget Emphasis, and Organizational Commitment On Budgetary Slack In Pemerintah Kota Pasuruan. Jurnal Ilmiah Mahasiswa Fakultas Ekonomi dan Bisnis Universitas Brawijaya, 1(1): 23-34.

Minanda, Yulpipa. 2009. Pengaruh Sasaran Anggaran, Komitmen Organisasi dan Ketidakpastian Lingkungan Terhadap Senjangan Anggaran Pemerintah Provinsi Sumatra Utara. Tesis Universitas Sumatra Utara, Medan.

Muindro, Reyowijoyo dan Deasy Rinarti. 2007. "Pengaruh Ketidakpastian Lingkungan dan Budaya Organisasi Terhadap Partisipasi Penganggaran dan Kinerja Manajerial”. Jurnal Bisnis dan Akuntansi, Vol 9. No.2 Agustus.

Mulyadi, 2001 Sistem Akuntansi, Edisi Ketiga, Cetakan Ketiga: Salemba Empat, Jakarta.

Nanda, Irfan dkk, 2013. Pengaruh Komitmen Organisasional terhadap Prestasi Kerja (Studi Pada Karyawan AJB Bumiputera Kantor Cabang Batu). Universitas Brawijaya, Vol.6 No.2.

Nitiari, Ni Luh Nyoman. 2014. Pengaruh Partisipasi Penganggaran, Komitmen Organisasi, Dan Ketidakpastian Lingkungan Pada Senjangan Anggaran. EJurnal Akuntansi Universitas Udayana. ISSN : 2302 - 8556.

Sugiyono. 2014. Metode Penelitian Kuantitatif Kualitatif dan R\&D. Bandung: Alfabeta.

Tagwireyi, Frank. 2012. An Evaluation of Budgetary Slack in Public Institutions in Zimbabwe. International Journal of Economics, 3 (4), pp: 38-41.

Wirjono, Endang Raino. 2013. "Hubungan antara Sistem Akuntansi Manajemen dan Ketidakpastian Lingkungan yang Dirasakan Terhadap Kinerja Manajerial". Fakultas Ekonomi Universitas Atmajaya Yogyakarta. Jurnal Ilmiah Akuntansi dan Bisnis, Vol. 836 No. 1 Januari 2013.

Zelvia. 2015 .Pengaruh Budaya Organisasi, Kepemimpinan dan Kepuasan Kerja Terhadap Komitmen Organisasi dan Kinerja Karyawan PT. TELKOM DIVISI REGIONAL I MEDAN. Skripsi. Universitas Sumatera Utara. 